SIR,-The minimum dietary sodium requirements have never been formulated satisfactorily. Whether a required level of $10 \mathrm{mmol} / \mathrm{day}$ has been inherited from primate and huntergatherer ancestors, as stated by $\mathrm{Dr}$ Trowell, is still open to argument. In the most gluttonous meat-eaters it could indeed have reached $60 \mathrm{mmol} / \mathrm{day}$ if they consumed something like 3 $\mathrm{kg}$ of lean meat per day, but this must have been much, much less in nolens-volens herbivores. The common food plants contain very little sodium.

It is not necessary to look for remote ancestors or for hunter-gatherers. These herbivores may be contemporary skilful cultivators. I refer to the highland Papuans in New Guinea for over a million of whom the staff of life is the sweet potato. ${ }^{1}$

The highland sweet potato provides some 1.1-3.1 mmol $\mathrm{Na} / \mathrm{kg}$. It is often responsible for $80-90 \%$ and over of the total food intake and it is improbable that other vegetable sources have higher rates. The contribution of animal matter does not count. The chance of imported salt reaching the autochthonous consumer is comparable to that of finding caviar on a European dining-table.

I had the opportunity to determine electrolytes in $24 \mathrm{~h}$ urines of a highland community. ${ }^{2}$ In groups of male and female adults and adolescents $\mathrm{Na}$ excretion was $1.7-2.1 \mathrm{mmol}$ a day. The lowest single value was $0.3 \mathrm{mmol}$. Three adult males had unusually high values $(6.5,8.8$, and $26.0 \mathrm{mmol}$ ) but they had had access to the scanty resources of the local missionary which did include imported salt. A control group of Dutch student-nurses consuming an institutional diet excreted $154-177 \mathrm{mmol} / 24 \mathrm{~h}$.

Although these highland Papuans were healthy and functional according to local standards, goitre was endemic. The people were small (adult males about $52 \mathrm{~kg} / 155 \mathrm{~cm}$, females $44 \mathrm{~kg} / 146 \mathrm{~cm}$ ). Protein intake was very low. The altitude was about $2000 \mathrm{~m}$; garden plots were on steep slopes and rainfall was heavy.

This community may not be the best example. However, these findings do show that the numerous sweet-potato farmers in the New Guinea highlands, deprived of outside contacts, can hardly achieve more than 6-8 mmol Na/24 h $(350-460 \mathrm{mg}$ $\mathrm{NaCl}$ ) in their customary diet. Such a level cannot be stated to be inherited because it is simply dictated by the ecological situation. If "inherited" is meant in an evolutionary sense such levels are shared with many herbivore animals.

It is true that the Papuans have a craze for salt but they also have one for tobacco. A distinction should be made between salt hunger and salt requirement. Hipsley, studying Papuans of the shore villages which are built on piles above the seawater, recorded $24 \mathrm{~h}$ urinary excretions of $8 \mathrm{mmol} \mathrm{Na}$ (range 1-35). ${ }^{3}$ One spoonful of seawater would provide that quantity.

Blood pressure in highland Papuans tends to be on the low side $;^{4-6}$ and, more significantly, no increase with age occurred.

In these highland communities potassium intake and excretion would be very high. We found levels between 105 and 180 mmol K/24 $\mathrm{h}$ in urine. It would be very interesting to study electrolyte balances of diarrhœea patients in such extreme conditions.

\section{Noolseweg 2}

Laren Nh 1251 GP, Netherlands

H. A. P. C. OOMEN

1. Oomen HAPC, Spoon W, Heesterman JE, Ruinard J, Luyken R, Slump P. The sweet potato as the staff of life of the Highland Papuan. Trop Geogr Med 1961; 13: 55-66.

2. Oomen HAPC. Nitrogen compounds and electrolytes in the urine of $\mathrm{New}$ Guinean sweet potato eaters. Trop Geogr Med 1967; 19: 31-47.

3. Hipsley EH, Kirk NE. Studies of dietary intake and the expenditure of energy by New Guineans. S Pac Comm Tech Paper 1965, no 147.

4. Whyte HM. Body fat and blood pressure of natives in New Gumea. Australas Ann Med 1958; 7:36-46

5. Barnes R. Incidence of heart disease in a native hospital of Papua. Med 7 Aust 1961; ii: 540-41.

6. Maddocks I. Blood pressures in Melanestans. Med f Aust 1967; in: 1123-26.

\section{VALPROATE, HYPERAMMONEMIA, AND HYPERGLYCINAMIA}

SIR,-Dr Coulter and Dr Allen (June 14, p. 1310) report increased blood ammonia levels in lethargic patients on valproic acid (VPA) medication without evidence of an associated liver dysfunction.

The blood ammonia levels they found do not, in our experience, cause acute neurological symptoms. Our doubts about a possible relationship between these levels and VPA induced lethargy are further strengthened by the VPA load test; the peak ammonia level associated with lethargy was only slightly above the normal range and we would not consider such a level as harmful.

Coulter and Allen also suggest a mechanism of hyperglycinæmia in patients taking VPA. Administration of VPA to rats significantly reduces the activity of the glycine cleavage enzyme system in the liver. ${ }^{1}$ The same enzyme defect has been demonstrated in ketotic hyperglycinæmia. ${ }^{2}$ This finding in the rat is a further evidence for the hypothesis that sodium valproate can induce a biochemical syndrome similar to that of the ketotic hyperglycinæmias. ${ }^{3}$

Department of Pædiatrics,

J. JAEKEN

University of Leuven,

3000 Leuven, Belgium

P. CASAER

L. CORBEel

* This letter has been shown to Dr Coulter, whose reply follows.-ED. L.

SIR,-We appreciate the comments of Dr Jaeken and colleagues. Hyperammonæmia in patients taking valproate is a newly recognised problem which is still poorly understood. Since submitting our letter, we have recorded hyperammonxmia in several other children with no evidence of liver disease who had become lethargic and who improved when the dosage of valproate was reduced. The degree of hyperammonæmia so far has been only modest, but is comparable to levels found in some patients with Reye's syndrome. ${ }^{4}$

Serious illnesses, including hepatitis, pancreatitis, and unexplained coma, and death have occurred in $3-5 \%$ of children taking valproate in two large series. ${ }^{5,6}$ Until the metabolic and toxic effects of this drug are better understood, modest elevations of blood ammonia should not be considered harmless when associated with clinical symptoms. Valproate is a potentially toxic drug, and its use needs to be monitored carefully, especially in children.

Departments of Pediatrics and Neurology,

University of Michigan Medical Center,

Ann Arbor, Michigan 48109, U.S.A.

David L. Coulter

SIR,- The case-report by Dr Coulter and Dr Allen prompts us to record our findings in two children who had encephalopathy during valproate therapy. In one of them the possibility of hyperammonæmia could be inferred and in the other there was unequivocal evidence of hyperammonæmia.

1. Kochi $\mathrm{H}$, Hayasaka $\mathrm{K}$, Hiraga $\mathrm{K}$, Kikuch $\mathrm{G}$. Reduction of the level of the glycine cleavage system in the rat liver resulting from administration of dipropylacetic acid: an experimental approach to hyperglycinemia. Arch dipropylacetic acid: an experimental ap

2. Tada K, Corbeel L, Eeckels R, Eggermont E. A block in glycine cleavage reaction as a common mechanism in ketotic and non ketotic hyperglycinemia. Pediat Res 1974; 8: 721-23.

3. Jaeken I, van Goethem C, Casaer P, Devlieger H, Eggermont E. Neutropenia durnng valproate treatment. Arch $D$ is Child 1979; 54: 986-87.

4. Engle WD, Baublis JV, Duff TE et al. Reye's syndrome in Michigan. In Crocker JFS, ed. Reye's syndrome II. New York: Grune and Stratton, 1979: 195-212.

5. Sherard ES, Steiman GS, Couri D, Bachman DS. Treatment of childhood epilepsy with valproic acid. Neurology $1980 ; 30: 31-35$

6. Coulter DL, Wu H, Allen RJ. Valproic acid in childhood epilepsy. $\mathscr{J} A M A$ in press). 


\section{Case 1}

A 12-year-old girl presented in July, 1977, with a clear history of temporal lobe epilepsy confirmed by EEG. After 2 weeks on sodium valproate, she was readmitted with further episodes of confusion, perseveration, and aggression. Following a short period of observation she was discharged on sodium valproate $800 \mathrm{mg}(30 \mathrm{mg} / \mathrm{kg})$ daily. Subsequently she had no further seizures, her general behaviour improved, and her appetite became normal. Liver-function tests before treatment were normal.

Some 9 months later seizures recurred, associated with diarrhœa, vomiting, and anorexia, and she was admitted with a possible diagnosis of sodium valproate toxicity.

Neurological examination revealed generalised hyperreflexia and some tremor. There was no cedema or hepatic enlargement. The serum valproic acid level was $127 \mu \mathrm{g} / \mathrm{ml}$ (therapeutic range 50-100). The drug was withdrawn. Some $36 \mathrm{~h}$ later she had further seizures and became unconscious. She was transferred to another centre, but shortly after admission she had generalised seizures; thiopentone, muscle relaxants, and intermittent positive pressure ventilation were required. Liver function tests at this time showed minor abnormalities; the serum bilirubin was $20 \mu \mathrm{mol} / 1$ (reference range, below 17 $\mu \mathrm{mol} / \mathrm{l} ; 1 \mu \mathrm{mol} / \mathrm{l}=0.059 \mathrm{mg} / \mathrm{dl}$ ) and aspartate aminotransferase $96 \mathrm{IU} / \mathrm{h}$ (range 6-18 IU/1). Some $24 \mathrm{~h}$ after admission she collapsed with circulatory failure, and died 2 days later.

The gross histology of the liver was normal. Neuropathological examination of the brain showed acute lesions, consisting of widespread "hypoxic" changes in nerve cells with foci of spongy necrosis in grey-matter, and the grey-matter contained enormous numbers of enlarged, pale astrocytic nuclei and scattered large cells of Opalski type. The lesions corresponded closely with those observed in fatal cases of hepatic encephalopathy, the principal association being with hyperammonæmia. ${ }^{1}$

\section{Case 2}

A $4 \frac{1}{2}$-year-old mentally handicapped girl with poor epileptic control was changed to a combination of carbamazepine (100 $\mathrm{mg}$ in the morning) and sodium valproate ( $400 \mathrm{mg}$ at night). This was subsequently readjusted to sodium valproate alone ( $800 \mathrm{mg}$ daily, a dosage greater than $40 \mathrm{mg} / \mathrm{kg}$ ). For a short period primidone $125 \mathrm{mg}$ at night was added and the dosage of sodium valproate was reduced stepwise to $400 \mathrm{mg}$ daily because peak blood levels of valproate were $219 \mu \mathrm{g} / \mathrm{ml}$. The valproate level fell to $118 \mu \mathrm{g} / \mathrm{ml}$ and at this stage an EEG showed a "disorganised record with sharp and slow components on the left side post-centrally, with sharp waves in the mid temporal lobe area". The record was diffuse with a possible localisation on the left side post-centrally. Seizure control was poor and the child seemed confused.

Pursuing a possibility of a urea cycle enzyme abnormality, we measured her plasma ammonia level and found it to be 85 $\mu \mathrm{mol} / 1$ (reference range 4-25); this abnormality was confirmed 2 and 4 weeks later. A small dose of phenobarbitone was introduced; on this combination (valproate $400 \mathrm{mg}$ daily with phenobarbitone $60 \mathrm{mg}$ at night) valproate levels were in the normal therapeutic range ( 75 and $74 \mu \mathrm{g} / \mathrm{ml}$ ) yet ammonia concentrations were high $(78 \mu \mathrm{mol} / 1)$. The ammonia level was 52 $\mu \mathrm{mol} / 1$ some $48 \mathrm{~h}$ after the drug was withdrawn and 3 weeks later the level was normal $(13 \mu \mathrm{mol} / 1)$.

During this period many conventional estimations of liver function were done; all were normal. When the sodium valproate was discontinued, the patients' white cell count was $9.2 \times 10^{9} / 1$ (lymphocytes $92 \%$, neutrophils $4 \%$, monocytes $3 \%$ eosinophils $1 \%$ ) and platelets $79 \times 10^{9} / 1.48 \mathrm{~h}$ later the plateletcount had increased to $333 \times 10^{9} / 1$, the white cell count being $10.4 \times 10^{9} / 1$ (neutrophils $53 \%$, lymphocytes $37 \%$, monocytes

1. Victor $M$, Adams RD, Cole $M$. The acquired (non-Wilsonian) type of chronic hepatocerebral degeneration. Medicine (Balt tmore) 1965; 44: 345-96.
$10 \%$ ). In parallel with the biochemical and hæmatological improvement there was a marked clinical improvement; the child became more alert and less ataxic. Subsequently seizure control has been maintained on carbamazepine and ethosuximide.

Patient 2 clearly had hyperammonæmia while on a high dose of sodium valproate but with blood valproate levels within the accepted therapeutic range. The clinical picture of the child and the EEG suggested a toxic encephalopathy, and the improvement that followed withdrawal of sodium valproate confirms the observations of Coulter and Allen. Conventional assessment of hepatic function failed to detect any abnormalities, and this supports the idea that there is a specific metabolic block and that conversion of sodium valproate to propionate and related compounds might inhibit carbamyl phosphate synthetase I activity, resulting in hyperammonæmia and encephalopathy.

Patient 1 could have had congenital hyperammonæmia due to partial enzyme defect though we would have expected such a patient to present at an earlier age with muscular rigidity, hepatomegaly, abnormal liver function, and mental retardation. The post-mortem findings suggest that this child may also have had a sodium valproate induced secondary hyperammonæmia.

Conventional liver function tests do not seem to provide a warning of valproate associated hyperammonæmia and loading tests on all children who are to be put on sodium valproate would be impracticable. Any patient taking sodium valproate who deteriorates or shows signs of increased seizure activity or signs of toxic encephalopathy, even with blood valproate levels in the therapeutic range, should have the plasma ammonia measured; the drug should be withdrawn if the ammonia concentration is raised.

Whiston Hospital,

Prescot, Merseyside

J. A. Sills

Bridgend General Hospital,

Bridgend, Mid-Glamorgan

R. H. TREFOR JONES

Department of Chemical Pathology,

Royal Liverpool Hospital,

Liverpool L7 8XW

W. H. TAYLOR

\section{RENAL FUNCTION AND $1 \alpha$-HYDROXYVITAMIN D THERAPY}

SIR,-Dr Paterson's report (May 31, p. 1164) on hypercalcæmia due to overdose with vitamin $D$ prompts us to report a case which illustrates the dangers of therapy with $1 \alpha$-hydroxycholecalciferol $(1 \alpha-\mathrm{OHD})$.

The patient presented aged 48 in 1972 in renal failure due to bilateral hydronephrosis and an atrophic left kidney. The surgeon found a retrocaval ureter on the right. After transposition of the ureter renal function was well maintained. In July, 1977, he started to complain of back pain. Investigations revealed plasma urea of $27.7 \mathrm{mmol} / \mathrm{l}$, creatinine $0.41 \mathrm{mmol} / \mathrm{l}$, calcium $2.00 \mathrm{mmol} / \mathrm{l}$, and phosphate $1.73 \mathrm{mmol} / \mathrm{l}$, and alkaline phosphatase $206 \mathrm{IU} / 1$. X-rays showed some sclerosis of the upper and lower regions of the vertebral bodies ("ruggerjersey" spine). Hand X-rays revealed subperiosteal erosions. Bone biopsy showed a gross excess of osteoid and active osteitis fibrosa. He was treated with aluminium hydroxide and, after the plasma phosphate had been controlled, $1 \alpha-\mathrm{OHD} 2 \mu \mathrm{g}$ daily was started. In May, 1978, plasma calcium was $2.94 \mathrm{mmol} / 1$ and plasma creatinine had increased to $0.74 \mathrm{mmol} / 1.1 \alpha$-OHD was immediately discontinued. In March, 1979, he again complained of back pain and the lumbar area was tender. At that time his plasma creatinine was $0.60 \mathrm{mmol} / 1$. In April, 1979, he was restarted on $1 \alpha-\mathrm{OHD} 0.5 \mu \mathrm{g}$ daily. He continued on this therapy until December, 1979. In July, 1979, when plasma calcium was $2.29 \mathrm{mmol} / 1$, plasma phosphate $1.7 \mathrm{mmol} / \mathrm{l}$, and alkaline phosphatase $90 \mathrm{IU} / 1$, plasma creatinine had already increased to $0.65 \mathrm{mmol} / 1$. Subsequently, plasma phosphate 